\title{
VISION OF VICTORIAN ECOLOGICAL DISASTER (BASED ON THE SELECTED NOVELS BY CINDY SPENCER PAPE)
}

\begin{abstract}
The problem of nature deterioration in the Anthropocene has become an important art concern, thus leading to analysis of ecological images in the texts of various genres. Our analysis of such imagery in a gaslight romance series is equally topical. The subject of the study is universe of the series of novels by Cindy Spencer Pape which centres around alternative nineteenth century London with highly developed steam engines and corresponding technology. Ecocritical approach is chosen as the research method of the study as the novels have powerful ecological imagery, which requires close analysis. The series covers a number of years, and so the ecological deterioration due to coal overuse can be traced through various London locales, which are described in different time frames, and the comparative reading of these descriptions provides the proof of ecological deterioration. It reveals the consistent ecological discourse within the series, its ties strengthened through steady layering of the images of nature, burdened with progressing pollution. There is social dimension to the issue, as the poorer urban residents are shown to be more effected by this problem due to their jobs, work and living conditions. The paper aims to reveal these numerous aspects of ecological imagery in the texts.

The results. Close text analysis of various levels allows us to decipher the multi-layered ecological images and dwell on the message they bear. As the environment degradation takes place in the past, the series allows us to describe its results as facts and compress its progress in time and space within the span of the novels setting. This intensifies the image of the catastrophe, makes it feel more immediate and pressing, thus becoming a powerful plot tool that results in search for solutions of the problem and alleviation of the existing results of coal overuse. This research is the basis of further analysis of ecological imagery in steampunk and gaslight romance as genres, fruitful in that regard.

Keywords: Cindy Spencer Pape; ecocriticism; image; deterioration; ecological disaster.
\end{abstract}

The series of novels by Cindy Spencer Pape, from which we have analysed the selected novels, bears an ecological message, a warning against air pollution and thoughtless use of natural resources. The research discusses the literary devices used in creating ecological imagery in the texts.

Ecocriticism is an approach towards literary text studies in their connection with the environment. It is a rather novel approach to analysing the function of the images of nature. Its functional emphasis is clearly seen in most definitions. According to Cheryll Glotfelty, 'ecocriticism is the study of the relationship between literature and the physical environment' (xviii). William Rueckert believes it to be 'the application of ecology and ecological concepts to the study of literature' (Rueckert, 2009, p. 107). He also highlights that nature is habitually marginalized in fiction, and it is for ecocritical research to uncover the means of its description. Sepril Opperman agrees with this approach, writing

Nevertheless, eco-literary discourse can address how literary texts articulate the silence of nature, and to what consequences. Thus, ecocriticism can explore what we can call a discursively manipulated nonhuman world in literature, and discuss how it gets marginalized or silenced by, or incorporated into the human language. (1999, p. 30)

This approach highlights the point that ecocritical focus is not restricted to the texts with a clear ecological message, but also to those where it is part of the chronotope.

Sven Birkerts asks if literature has a place in the ecological cause and what that place may be. He writes: 'Should it be publicized to help advance the cause of natural environment?' (1996). This medium of highlighting the issue is important in contemporary culture. Gretchen Legler accentuates its cultural aspects: 'analysis of the cultural constructions of nature, which also includes an analysis of language, desire, knowledge, and power' (2010, p. 227). The focus on linguistic aspects of the text is natural in ecocriticism according to Wendy Wheeler, who offers a historical analysis of the development of ecocriticism (2008).

Linguistic means of accentuating ecological imagery in a text are varied. To uncover these images of nature we need to conduct text analysis and interpret the results based on the cultural image of nature. This paper focuses on such analysis of London's ecological disaster images in the series of novels by 
Cindy Spencer Pape, namely book one (Steam and Sorcery) set in 1951, book 4 (Moonlight and Mechanicals) set in 1959, and book 6 (Ashes and Alchemy) set in 1960. Other novels of the series are set in different locations and ecological imagery in them is far less pronounced than in the closely analysed arch of the three selected novels. According to Chris Baratta, the often overlooked aspect of fantasy and science fiction is 'its importance to serve as a reflection of reality' (2012, p. 3). In this study we seek to analyse the vision of ecological disasters in alternative London. As opposed to the nostalgic approach that allows the reader 'a recreational space to examine the natural world imaginatively', these novels occupy the other extreme of the scale (Brawley, 2014, p. 30). They highlight ecological issues and their effects.

The application of ecocritical analysis to the series of novels Gaslight Chronicles by Cindy Spencer Pape a progressing timeline is useful as it allows us to use the functional aspect more fully the use of extensive comparison.

The universe of the Gaslight Chronicles series combines magic and accelerated technological development. The overuse of coal in steam-powered machines, such as dirigibles, cars, factory equipment, household appliances, etc. has led to the rapid degradation of air quality in London in the 1950s in this fictional universe. The residents of London are forced to wear facemasks that let them breathe in the streets; otherwise, they die of the illness called 'black lung disease' caused by constant coal soot inhalation.

The image of ecological degradation is traced in two main locations - Whopping, indicative of the poor neighborhoods of London in 1951 (Steam and Sorcery) and 1959 (Moonlight and Mechanicals), and central London as the place where more well-to-do people reside in 1951 and 1959, and in 1960 (Ashes and Alchemy) - image of London as a whole. This also adds social dimension to the issue.

First of all, the description of central London is offered as traditional for the fiction set in those times: 'The cold snap they'd been enduring had left small patches of ice on the road, and he made sure his footing was solid before he held out his hand for Dorothy to alight' (Pape: Steam \& Sorcery). This description is functional; it accompanies a habitual action. The noncommittal description is clearly a part of the novel chronotope, but it also serves the baseline example of Opperman's 'silence of nature', as it is merely a part of the scene setting (1999). As contrasted to it, most descriptions of nature in the text have definite ecological imagery that underlines the decay of the ecological situation with time.

The situation in the richer locales of London, in particular the Regent's Park, is described as follows: 'The gardens were just beginning to bloom, and Caroline let her senses fill with the shades of green, the sound of the soft breeze, the warmth of the sun and the fragrances of rich soil and budding blooms' (Pape, 2013). This nostalgic landscape harshly clashes the other descriptions of London nature in the novel.

There are indications of deterioration of air quality in the Mayfair too, and they undermine the traditional romantic imagery of the night outside the ballroom: 'Surely there would be stars visible, if only they weren't hidden by fog and coal smoke. It was such a fantasy of an evening that somewhere inside, Caroline had expected stars' (Pape, 2013).

Still, coal smoke is second to fog in hiding the view and, hence, is a minor issue. But this mention of coal smoke ruining a perfect romantic scene underlines the growing omnipresence of the issue.

Unlike this mention, the description of Whopping in 1951 bears the traces of pollution due to the extensive use of coal in the working areas of London in this universe: 'The pungent reek of rotting food, polluted water and human waste filled Merrick's flared nostrils as his black-clad form slipped through the murky darkness. Though keen senses were part of his birthright as a Knight, and have saved his life on more than one occasion, he spared a moment to regret that the rising fog only served to intensify the stench' (Pape, 2013).

These smells 'The pungent reek of rotting food, polluted water and human waste' are indicative of the poor ill-kept part of London, but the mention of 'the murky darkness' and 'the damp, sooty night' underlines the presence of coal pollution through colour-related epithets. Black is associated with the pollution in the text logically, as coal ash is black in colour, but in addition black is associated with evil, bearing a negative connotation.

This is the result of the active use of steam engines in the work of this part of the city: 'The building hummed with the sounds of mechanized loading and stacking equipment and it belched vast columns of coal smoke and steam' (Pape2013). The negative connotation of the image is underlined with the verb choice 'belch' and alliteration on sounds [s] and [k], which could represent the sound emanating from the machines.

There is a social layer to the issue - though the results of extensive coal use are more evident in Whopping, the presence of automated washing and drying machines is an abnormality, such amenities are generally used by the richer city residents: 'The Wapping alleyway boasted none of the gas lamps of his Mayfair neighborhood...', 'Merrick was momentarily surprised that such a poor neighborhood should boast automated washing and drying machines, but he didn't allow himself to linger over the thought' (Pape, 2013). This underlines the strict division of London into areas according to social stratification. The richer London residents are feeling the issue less acutely, but still reap all the benefits. This distinction is also the key point in the novels' ecological discourse - it primarily includes the social stratification, but gradually the pollution spreads and becomes a problem for all the residents. 
The image of the growing natural degradation is expressed through the child character of the book, who says during his first trip outside London 'Who'd have ever imagined there was so much green in the whole world?' (Pape, 2013). His governess rationalizes his remark: 'Even in the vast space of Hyde Park, the green was so overlain with soot that it wasn't the same' (Pape, 2013). This complementing use of different voices to express emotional attitude and provide an explanation for the unadulterated child's reaction provides another layer to the image.

The next description in Moonlight \& Mechanicals, year 1859, bears even stronger imagery of the ecological degradation. The image of central London is portrayed as follows:

Coal smoke clogged the air of London until almost every building façade was black. Blight stunted the trees and even in Green Park and Kew Gardens, there was precious little green to be found. Hawkers still cried their wares from street corners, but now they kept scarves over their faces, or air masks if they could afford them. Every day, Londoners too poor to employ air filters in their homes died of black lung, and other respiratory illnesses as if they were coal miners. Couldn't the blighters in the Royal Society see the urgency of the problem or the elegance of the solution? (Pape, 2012b).

The focus on colour epithets is more pronounced here - the pollution-associated black is mentioned, followed with a pun on the colour 'green' - the park named for it has little really green, it is mostly black due to the smoke. The connection between the collective name for the pollution 'blight' and people, called 'blighters' is noteworthy. Through this repetition they are pointed out as the cause of the problem. Cheryll Glotfelty underlines: 'If we are not part of the solution, we are part of the problem' $(2009$, p. xxi) in ecocritical discourse, and this aspect is important to the text of the series.

Another description of the part in the text is as follows: 'A short ride later, they turned into the park and Wink looked sadly at the black scrubby grass, the stunted trees and scraggly shrubs where once there had been so much green' (Pape, 2012b). It is dominated by a series of epithets: 'the black scrubby grass', 'the stunted trees' and 'scraggly shrubs', as opposed to the prior condition described with only one phrase: 'so much green'. This opposition is emphasised on multiple levels. Firstly, the figurative means, used to describe the pollution, outnumber the ones used for the pristine condition. This misbalance shows the text's focus on the ecological disaster going on. Secondly, the morphological composition of these epithet structures is fundamentally different. The first three ones include the adjectives or past participles, defining the characteristics of nouns, while 'so much green' is made of an adverb and a substantivized adjective. This final combination cre- ates a fuzzy picture, which relies greatly on our image of 'green' and its connotations. Such openness allows for a maximized image of ecological wellbeing as opposed to the harshly defined individual features of the polluted version. This polluted version also depends on the images of malformation: 'the black scrubby grass' involves the omnipresent colour epithet and the notion of size inferiority; 'the stunted trees' strengthens the image with the added meaning of hindered normal development; 'scraggly shrubs' capitalizes on this accumulation of images of abnormal structure with the notion of faulty formation. This accumulation creates the clearly defined image of abnormality of such an ecological state and stresses the nostalgic feelings of the characters towards the clean nature. Such a condensed and intensive description has the notion of secular apocalyptic prophesy (Garrard, 2012) attached due to the fact that it is described in the past tense, despite it being fantastic.

According to Karla Armbruster and Kathleen R. Wallace, ecocritical analysis can bring attention to local environmental landscapes in a creative way:

By combining attentiveness to natural phenomena and processes with an eloquent voice and a narrative line, nature writing has not only helped to reinvigorate and reintegrate education, but has also inspired environmental activism and confirmed the distinctiveness and value of local landscapes. (2001, p. vii)

From such a point of view the London landscapes in this fictional universe can be viewed as a warning, especially taking into account the underlying contrast to the historical images, as in the example above.

The sound pattern of the sequence of epithet structures adds another facet to the image. Sound repetition creates the audial image. In this instance, the repeated sounds are $[\mathrm{s}],[\mathrm{k}],[\mathrm{t}]$ as highlighted further: 'the black scrubby grass, the stunted trees and scraggly shrubs'. These voiceless consonants both reflect the image of the sound such barren landscape produces and strengthen the unpleasant audial aspect of the image. All the characterising words begin with the same sound [s], which also gives this sequence of epithet structures inherent unity. This unity is strengthened also by the similarity of sound patterns of the first and third epithets 'scrubby' and 'scraggly' - they both begin with the same consonant cluster [skr], followed by a voiced vowel and long consonant, also both of these words end in the same vowel. Such profound similarity in sound emphasises the unified image of a desolate landscape. The phonetic level is essential for the all-encompassing image, as it incorporates an auditory layer into the characteristic.

Another token example of socialized ecological imagery is the aforementioned concept of 'air masks'. They symbolize the effect the pollution with coal has on the everyday life of Londoners, the dangerously 
poor quality of air; and highlights that it effects the poorest the most, as they can ill afford to ride and even to buy the necessary safeguard devices.

The image of Wapping in Moonlight and Mechanicals has also changed over the eight years that separate the events of the books, containing the description of this location: 'The stench of the river, horses and human waste that he remembered was masked somewhat by the thick miasma of coal smoke that now cloaked London as a whole' green' (Pape, 2012b). The repetition of the verbal means of creating image with the 1951 description (stench, river as synonym to water, human waste) is noteworthy, but now they are considered the lesser of the two evils. The dominant feature is 'the thick miasma of coal smoke'. The ecological degradation is made evident through the word choice inside the phrase: stench as compared to miasma. It also is remarkable if the comparison spans both descriptions:

\begin{tabular}{c|l|l} 
Features & \multicolumn{1}{|c|}{1851} & \multicolumn{1}{|c}{1859} \\
\hline $\begin{array}{c}\text { Collective } \\
\text { natural odour }\end{array}$ & the pungent reek & Stench \\
\hline The Themes & polluted water & $\begin{array}{l}\text { The stench of the } \\
\text { river }\end{array}$ \\
\hline Coal smoke & $\begin{array}{l}\text { the murky darkness } \\
\text { the damp, sooty night }\end{array}$ & $\begin{array}{l}\text { the thick miasma } \\
\text { of coal smoke }\end{array}$
\end{tabular}

This short comparative argument shows that the pollution problem has worsened, especially due to the coal exhaust, caused by the technological progress of steam-powered machinery without any nature preserving efforts. The distant interconnection of the descriptions of Wapping in these novels underlines the systemic nature of the ecological discourse in the series. Such steady layering of the images with the definite accent on the worsening of the situation creates the image of this catastrophe. The partial repetition of figurative language in distant descriptions is a method of creating the consistent ecological discourse in this series of novels.

There is direct comparison of the situation in Wapping in 1851 and 1859:

In those days, local gangs and other waterfront lowlifes had been a bigger worry than the soot and smoke that clogged the air. Today, the gangs still operated, but most of the populace didn't worry about them too much. The average worker assumed lung disease would kill him before the criminals had a chance. (Pape, 2012b)

Here the social effects of air pollution are compared to criminal human activity and stated to be the deadlier issue. Such a statement gives voice to the effects of the ecological catastrophe and implies it being a heinous crime against people.

Another important point of this description is the phrase 'London as a whole' as contrasted to the mention of Wapping as 'this part of London' in 1951 portrayal. This unification shows that the problem has ceased to be a solely social issue, it now is omnipresent.

The werewolf character possessing heightened senses is described seeing London as follows:

The pea-soup fog mixed with coal smoke to create a nearly solid layer of darkness on the streets. The smells of human waste, soot and rotting garbage were stronger at this level, but Liam had long ago learned to ignore those. They were nothing more than the background odor of town. (Pape, 2012b)

The image of 'a nearly solid layer of darkness' is a means of visualizing the issue through colour and texture.

The description of air quality as of 1860 includes no territorial or social differentiation. The characters of Ashes and Alchemy travel all around London to both poor and rich parts, and no difference is noted. The only social difference is retained in the amenities available to the poor and rich residents of London new technologies are only accessible to the affluent people.

The description of a moderately wealthy London neighbourhood is as follows: 'It was a modest neighborhood, exalted by her standards, but not frequented by the highest of the high. Narrow, well-kept homes were shrouded by the smoke-laden fog and the darkness, but she knew what they looked like' (Pape, 2014). In this description the use of the verb 'shroud' is very revealing, as in addition to its meaning 'to conceal' and 'to cover', it also has the definition 'to dress for burial'. This verb invokes an image of an impenetrable veil. The fact that 'the smokeladen fog and the darkness' are mentioned as equal reasons of the poor visibility is telling, especially taking into consideration the fact, that the ecologically laden image is mentioned first, and thus both bear more notice and prominence.

The air pollution in this book is likened to social and supernatural villains: 'Constantly looking over her shoulder for cutthroats, or even worse, vampyres, she soldiered on. Despite the smoke that choked the city, those two elements continued to thrive' (Pape, 2014). Deteriorating ecological conditions are a hindrance to mundane things, including walking along the streets, and only desperate criminals and vampires with their unnatural powers of the undead survive outside. The emphasis on the fact that the undead are comfortable under such conditions show the unnatural state of London's air, as vampires are described as unnatural and evil: 'The vile, bloodsucking fiends', 'the monster's filthy talons', 'such unnatural creatures' (Pape,2014). As the offered evidence shows, vampires are not called by any nouns denoting people, moreover, they are 'destroyed' like things, for they are not alive. This fantastic connection proves the unnatural state of the ecology and its deadliness.

This connection is highlighted further in the novel: 'She didn't even wear a breathing mask. With the 
coal smoke polluting the London air, that was tantamount to a death sentence, if the vampyres or criminals didn't get to her first' (Pape, 2014). The image of the poor state of the environment is reflected here in its danger for the character. Wearing a breathing mask to lessen the negative effects of the highly polluted air is paramount for survival. This image of nature so polluted, it is basically uninhabitable without further devices. This signifies the next step in the deterioration of atmosphere in the city, its detachment from the natural state of being into a dimension of its own that is ruled by the smoke-choked air and its consequences.

The likening of lack of the breathing mask to a capital sentence also provides a powerful image and emphasises the severity of pollution in London in this universe. As it can be observed throughout the series, the environment in London is deteriorating. In 1851, it was described as a city with a mild problem of smoke pollution in the poorer parts, which does not cause real issues in everyday life. In 1860 , this pollution has overtaken the whole city and is causing obstacles at every step.

The unnatural situation is underlined by means of inclusion of the two types of inhabitants it breeds criminals, described as desperate people, and vampyres, the fictional undead unnatural creatures. This also leads to the conclusion that the man-made deterioration of the ecosystem of the city is by that moment acting against people, limiting their place and comfort in the habitat of the city.

Throughout the novels, the attempts to change the situation are described. First, in Moonlight and Mechanicals, one of the protagonists - a magically gifted mechanic Winifred - offers a solution in the form of alternative energy sources: 'She'd just finished presenting her paper on the beneficial properties of wind and electric power over coal' (Pape, $2012 \mathrm{~b}$ ). Her paper is laughed at due to the gender related restrictions of the Victorian era, superimposed over the business interests of the established coal-mining industrialists:

The problem, missy, is that our economy is built on coal. Reducing its use costs jobs'. She couldn't see the owner of that particularly patronizing tone either, but it obviously met the approval of the audience, because another round of boos and jeers broke out. (Pape, 2012b).

Further discussion of the topic turns into a succession of demeaning remarks from the audience. The negative reaction is underlined with genderrelated word choice (missy, girl), sexist suggestions ('Go back to your needlework, girl. It's where you belong', 'Better yet, on her back') and ellipsis use (Pape, 2012b).

It is noteworthy that this solution is partially implemented in the next novel by the laird of the island off the Scottish coast: 'Steam engines are so foul to the atmosphere, and we have to bring in coal from the mainland. I read a paper about using wind to generate electrical power, so we're testing it out as best we can' (Pape, 2012a). The presence of such an attempt to preserve nature is especially well-placed, as the people and the laird of the island are magically connected with it to the extent that the laird cannot leave it for prolonged periods of time. This may be viewed as symbolic due to the direct dependency of the island's inhabitants on the environment they live in on the desire to preserve it.

There is also an example of another approach to improving the situation - through battling the results. In Ashes and Alchemy the main intrigue of the novel revolves around a mad scientist, who invented a bacterium that helps the human organism rid itself of the coal ash inhalation byproducts through bodily fluids, but the exposure to the artificial illness proved to be fatal:

Each one seems to be completely encased in some sort of tiny jellyfish-like bacterium. The organism itself is dead, and I haven't yet been able to separate one from around the carbon particle in the centre. From what I've seen so far, it's as if the bacteria took particles of soot out of your daughter's body and actually pulled them out through the sweat glands in her skin. (Pape, 2014)

The illness kills all its victims, and the only survivor has lived only because she is a magical being, and her magic saved her. In such a way, the concept of treating separate ill consequences of air pollution instead of addressing the issue as a whole is condemned.

Though the effects of the illness are used to also show the profundity of the situation. It transfers the soot inhalation residue from the lungs to the skin. The little girl with fey blood is only four years old, but despite that, when infected with the bacteria, she is covered with soot: 'Black soot seemed to crust almost every inch of the garment, as well as Ivy's face, hands and, well-everywhere else' (Pape, 2014). This amount of soot being extracted from the body over a several hour period shows that poor London residents are facing grave danger to their health because of the polluted state of London's air.

To conclude, the image of the ecological catastrophe in the series of novels by Cindy Spencer Pape is created through the judicious use of figurative language. To uncover the environmental message, a comprehensive analysis of all nature descriptions was made. The descriptions of London all accentuate the black colour of buildings, the black fog, and the rain mixed with coal ash falling onto the streets. They mostly depend on visual and olfactory perception, in addition the sound aspect of the images greatly relies on alliteration, most often of the sounds [s] and $[\mathrm{k}]$, to imitate the unpleasant mechanical sounds. The most notable figurative means of image creation are colour-related epithets and distant repetition. The 
social aspect as part of the ecological imagery enriches the message of the text and involves humans into the ecological discourse in the series.

The image of pollution due to the unchecked use of coal is omnipresent in Gaslight Chronicles by Cindy Spencer Pape, especially profoundly detailed in the analysed novels due to their setting. Its importance is in the message it sends. The consistent ecological discourse in the novels is achieved through distant partial repetition in the descriptions of the images of deteriorating nature throughout the series. The approach to the issue as historical gives the ecological disaster image in these novels additional power. The descriptions highlight its gradual deterioration over time and the negative effects it has on the living conditions of the characters of the series. The fictional compression of the ecological issues of a big industrial city in both time and intensity is intended as a warning message through creative use of nature imagery in London landscape in this series.

Two ways to alleviate the issue are offered in the text, one battling the cause and the second erasing the results. The first one is shown as a success, while the second one kills, hence showing how flawed the idea itself is.

\section{References}

Allewaert, M., \& Ziser, M. (Eds.). (2012). Ecocriticism. American literature, 84(2). Duke University Press. https://doi.org/10.1215/ 00029831-1587332

Armbruster, K., \& In Wallace, K. R. (2001). Beyond nature writing: Expanding the boundaries of ecocriticism. University Press of Virginia.

Baratta, C. (2012). Environmentalism in the realm of science fiction and fantasy literature. Cambridge Scholars.

Birkerts, S. (1996). Only God can make a tree: The joys and sorrows of ecocriticism. In The Boston book review, 3.1. https://www.asle.org/wpcontent/uploads/ASLE_Primer_Birkerts.pdf

Brawley, C. S. (2014). Nature and the numinous in mythopoeic fantasy literature. McFarland \& Company, Inc., Publishers.

Garrard, G. (2012). Ecocriticism. Routledge. https://doi.org/10.4324/ 9780203806838

Glotfelty, C. (2009). The ecocriticism reader: Landmarks in literary ecology. The University of Georgia Press.

Legler, G. T. (2010). Ecofeminist literary criticism. In Ecofeminism: Women, culture, nature (Pp. 227-238). Indiana Univ. Press.

Oppermann T., S. (1999, December 15). Ecocriticism: natural world in the literary viewfinder. In Hacettepe University Journal of Faculty of Letters, 16.2, 29-46.

Pape, C. S. (2012a). Kilts \& kraken. Carina Press.

Pape, C. S. (2012b). Moonlight \& mechanicals. Carina Press.

Pape, C. S. (2013). Steam \& sorcery. Carina Press.

Pape, C. S. (2014). Ashes \& alchemy. Carina Press.

Rueckert, W. (2009). Literature and ecology: an experiment in ecocriticism. The ecocriticism reader: landmarks in literary ecology (Pp. 105-123). The University of Georgia Press.

Wheeler, W. (2008, January 01). Postscript on biosemiotics: Reading beyond words - and ecocriticism. New formations, 64, 137-154.
Дарія Хохель

Кам'янець-Подільський національний університет імені Івана Огієнка, Україна

\section{ВІЗІЯ ВІКТОРІАНСЬКОÏ ЕКОЛОГІЧНОЇ КАТАСТРОФИ (НА ОСНОВІ ВИБРАНИХ РОМАНІВ СІНДІ СПЕНСЕР ПЕЙП)}

\begin{abstract}
Проблема погіршення стану природи в антропоцені стала важливим аспектом художнього дослідження, що привело до аналізу екологічних образів у текстах різних жанрів. Запропонований аналіз таких образів у серії романів жанру "gaslight romance» також $\epsilon$ актуальним. Предмет дослідження - художній світ серї романів Сінді Спенсер Пейп, зосереджений навколо образу альтернативного Лондона XIX століття з високорозвиненими паровими двигунами та відповідними технологіями. Методом дослідження обрано екокритичний підхід, оскільки романи мають потужні екологічні образи, дослідження яких реалізується шляхом філологічного аналізу тексту. Серія охоплює низку років, і тому погіршення екології через надмірне використання вугілля можна простежити через різні локації Лондона, описані в різних часових пластах, і порівняльний аналіз цих описів служить доказом погіршення екології. Так розкривається послідовний екологічний дискурс у серії, його зв'язки зміцнюються за рахунок постійного увиразнення образів природи, обтяжених прогресуючим забрудненням. Ця проблема має соціальний вимір, оскільки бідніші жителі міст більше страждають від забруднення через роботу й побутові умови. Стаття має на меті розкрити ці численні аспекти екологічних образів.

Ретельний аналіз тексту різних рівнів дав можливість розшифрувати багатошарові екологічні образи та зупинитися на їхньому значенні в романах. Оскільки деградація навколишнього середовища відбулася в минулому, серія описує її результати як факти і стискає її прогрес у часі та просторі дії романів. Це посилює образ катастрофи, змушує відчувати їі більш нагальною й актуальною, перетворюючи їі таким чином на потужний сюжетний інструмент, результатом якого є пошук шляхів вирішення проблем і полегшення наявних наслідків надмірного використання вугілля. Стаття є основою для подальшого аналізу екологічних образів стімпанку та «gaslight romance» як плідних для такого дослідження жанрах.
\end{abstract}

Ключові слова: Сінді Спенсер Пейп; екокритика; образ; виродження; екологічна катастрофа. 